UDC 342.9:004(477)

DOI https://doi.org/10.32837/chc.v0i41.424

\author{
Menso Iryna Volodymyrivna, \\ PhD in Law, \\ Senior Lecturer at the Civil and Labor Law Department \\ Odesa National Maritime University
}

ORCID ID: 0000-0003-0211-1567

\title{
LEGAL REGULATION OF E-COMMERCE IN THE EUROPEAN UNION
}

Formulation of the problem. Gradually, a new concept of "e-commerce" appeared and became established in business and legal practice, but the legal basis for regulating e-commerce relations in the world is just beginning to be created. At the level of international organizations and legislation of some countries only since the 90s of the twentieth century. Work began on the adoption of comprehensive regulations on the regulation of relations arising from the commission of legal acts through telecommunications networks, which is associated with the complexity and novelty of e-commerce.

The state of research of the topic. Relationships on the use of electronic documents, electronic digital signatures, e-commerce (trade) are studied in the works of: M. Dutov, S. Petrovsky, A. Baranov, A. Chuchkovskaya, O. Stepanenko, I. Balabanov, A. Vershinin, I. Zhilinkova, M. Braginsky, V. Kopylov, V. Naumov, A. Tedeev, A. Shamrayev and others.

The aim of the article is a scientific and theoretical study of the legal relationship of e-commerce, the legal regime of electronic documents and electronic digital signatures at the supranational level in the EU given the formation of the information society and the use of new information and communication technologies.

Presenting main material. The modern world economy is currently at the stage of formation of the information society under the influence of the development of information technologies, the latest means of communication, the promotion of the global Internet. E-commerce involves the conclusion of commercial contracts online using electronic means of communication. It is, first of all, about the promotion of goods or services on the market through the global Internet, as well as settlements using electronic payment systems. The e-economy (web economy) deals with digital data and includes ways to make a profit using the Internet. The components of the electronic economy (web economy) are: Online stores, Online media, online advertising, online entertainment, etc. Legal regulation of this segment of the world economy is complicated by the rapid change of technology and the high level of globalization of economic relations. The EU has an e-Europe program aimed at the widespread use of the latest information technologies by EU citizens, the formation of new, unified supranational legislation at the EU level. The main principles of legal regulation of e-commerce in the EU include, in particular, the following: implementation of the principles of the internal market in ensuring the free movement of information society services; ensuring respect for human rights and freedoms in the use of the latest means of communication; innovative business development and investment in research; observance of consumer rights in e-commerce.

Since 1996, e-commerce legislation has been in place in the EU. In 1997, the European Commission adopted the European E-Commerce Initiative, and later in 2000, the EU Directive on certain aspects of information society services and e-commerce in the internal market (the E-Commerce Directive) was adopted. This Directive is based on the principles of the EU internal market, in particular the freedom of establishment and the freedom to provide services, as well as the provisions on the harmonization of national laws. The Directive states that the fragmentation of national leg- 
islation may create obstacles to the development of the information society, as well as fail to ensure adequate protection of the rights and interests of individuals and legal entities. That is why it is necessary not only to harmonize the current legislation in the field of electronic commerce, but also to ensure uniform legal regulation in this area [1].

The 2000 EU E-Commerce Directive provides for the development of the EU internal market for information society services (services provided at the customer's individual request (distance), usually for a fee, by electronic transmission and storage). In addition, there are services for providing search and information online, providing access to databases, transmission and storage of information, exchange of commercial correspondence. According to the Directive, EU member states may not restrict the provision of information society services within the EU. EU law establishes the principle of responsibility of the country of origin of the service. The Directive applies to services provided by suppliers from the territory of the EU and does not apply to services provided from the territory of third countries. It is important in this context to determine the country from which the service is provided. The Directive, taking into account the case law of the Court of Justice, understands the place of establishment of the service provider - the place of actual economic activity, which should provide for the establishment of a commercial enterprise for an indefinite period. According to this rule, the location of the service provider is not the actual location of the data of its website, but the center of its actual economic activity, ie the place from which the provision of relevant services [2]. The implementation of the principles of the EU internal market is that the provision of information services does not require prior permission from public authorities. In this case, the service provider must provide constant access to information about yourself, in particular, brand name, location, e-mail address. The issue of taxation of economic activity on the Internet remained outside the scope of the Directive.

The EU e-Commerce Directive contains provisions relating to contracts concluded electronically, in particular through the Internet. According to Article 9 of the Directive, EU Member States must exclude from national law requirements for the form of contracts which prevent the use of electronic contracts. In addition, the Directive obliges EU member states to remove obstacles to the implementation of contracts electronically at all stages: from discussion and conclusion to the storage of their electronic originals [3].

The general principle of regulating contracts concluded electronically is defined as legal non-discrimination solely on the basis of their "virtuality". Thus, it is necessary to give electronic contracts the legal force that exists for contracts concluded in the traditional way. However, the Directive does not remove restrictions on transactions via the Internet. The national laws of the EU member states may set certain requirements for such agreements, but only those that can be fulfilled in a digital environment: requirements to ensure the identification of the person who signed the document and guarantees the invariability of the document sealed with an electronic digital signature. In addition, restrictions may apply to contracts when it is necessary to notarize them [4].

The EU E-Commerce Directive states that EU legislation in the field of consumer protection also applies to e-commerce. Under EU law, advertising letters, commercial messages (spam), which are received in large numbers by consumers, are an invasion of privacy and cause objections. At the same time, on the other hand, it is one of the effective ways to promote goods and services on the Internet, which, among other things, promotes the development of e-commerce. In EU Member States where commercial communications are allowed, opt-out filters should be developed to ignore disinterested users. In this case, such e-mails should contain the necessary elements to facilitate such disregard by users, and the receipt of such messages should not be accompanied by additional costs for users [5]. Since 2001, the European Commission has launched a debate on the development of EU contract law, which also includes issues related to the legal regulation of electronic contracts, which are designed to facilitate the conclusion of cross-border contracts.

The problem of recognizing "electronic contracts" along with contracts set out on physical media concerns issues of private international law, as transactions concluded via the Internet contain a foreign element, ie the question arises as to which law should be applied. Under EU law, the principle of autonomy of the parties applies, according to which the parties have the right to choose the right applicable to their contract. In the absence of the consent of the parties, the law of the country most closely connected with the transaction shall apply. In the process of preparing the draft EU Directive on e-commerce, the European Commis- 
sion proposed to establish a conflict of law between the law of the country of the service provider, but such a proposal was not accepted by consumer protection societies [6].

Equally important is the issue of international jurisdiction. Under current EU law, in the event of a dispute between a consumer of a service from one EU Member State and his supplier from another EU Member State, the consumer must go to court in his place of residence. This can lead to significant costs for service providers and the need to sue in different countries. As the Directive obliges EU Member States to encourage the development of alternative dispute resolution, it is interesting to establish a European Extrajudicial Network (EEJ-Net), which should be used as a place to resolve conflicts between consumers and information service providers. The development of electronic means of communication has necessitated the introduction of electronic signatures and related services related to their legal registration and recognition. This institute aims to overcome existing barriers to the use of electronic means of communication and e-commerce. At the same time, clear legal regulation of the use of electronic signatures will help increase trust in them, and, accordingly, the introduction of new technologies. Legal unregulated electronic signatures are the reason for the lack of established conceptual apparatus and terminology in this area [7].

Given the complexity and novelty of the relationship that arises when making transactions via the Internet, in 1996 the UN Commission on International Trade Law (UNCITRAL) adopted the Model Law "On E-Commerce", and in 2001 the Model Law "On Electronic Signatures". The reason for the development of these laws was the emergence of new means by which the parties exchange information with each other, using modern methods of communication when concluding transactions.

These model laws are designed to serve as a model for assessing and updating the laws of the world and the practice of their application in the field of trade relations using modern methods of communication. These model laws contain general principles for regulating e-commerce and electronic signatures and are the minimum standards for regulating transactions committed electronically. The need for legal regulation of electronic signatures is due to the fact that in the era of global informatization, it is difficult to solve any problems without modern means of signing documents that legally formalize the conclusion of legal acts [8].
The European Union, given the importance of the problem of legislative regulation of electronic digital signatures, has considered the regulation of relations arising from the conclusion of transactions electronically. In 1999, the EU Directive № 1999/93 / EC “On the procedure for the use of electronic signatures" was adopted, according to which an electronic signature is data in electronic format that is attached to or logically related to other electronic data and is a method establishing authenticity (Article 2). Special legal regulation is provided for an electronic signature, which must meet the following criteria: be uniquely associated with the signatory; be able to identify it; to be created on the basis of the means which are under personal control of the signatory; be linked to the data to which it relates in such a way that any further change in the data can be detected. The rapid technological development and the global extraterritorial nature of the Internet are the foundations of the ideology of openness to various technologies and services related to the conformity of the original data, including through electronics.

Electronic signatures have become widespread in various fields of human activity, which has led to the development of new products and services related to them. The definition of such products and services cannot be limited to the issuance of certificates and work with them. It also applies to registration services, time stamping, instructional services, computer-related services, electronic signature consulting services [9]. The EU internal market enables certification service providers to work with foreign clients, which increases their competitiveness and opens up new prospects for consumers and businesses to securely exchange information and trade across borders by electronic means. An important factor is the provision of certification services by government organizations and individuals, provided they comply with national legislation. EU member states must ensure proper conditions for maintaining the competitiveness of providers. An important factor is the EU Directive on electronic signatures to establish a balance between the needs of consumers and businesses [10]. The Directive sets out the requirements for security features for signature reproduction, which obliges EU Member States to develop and implement such devices in a timely and effective manner.

The EU Directive is a significant contribution to the use and legal recognition of electronic signatures at EU level. Legal regulation is not required 
for electronic signatures used to secure relationships based on a voluntary basis. The Directive states that it is not aimed at harmonizing national rules relating to contract law. The provisions of the Directive concerning the legal force of electronic signatures must comply with the requirements of the national legislation of the EU Member States in this area [11].

The EU is currently harmonizing the criteria for the legal validity of electronic signatures. The national law of the EU member states sets requirements for ensuring the legal force and identity of electronic signatures, in particular, electronic signatures based on modified certificates (electronic certificates linking the data of signature verification with the subject and confirming their identity) are used. to ensure a higher level of protection [12]. The EU directive is designed to promote the use of electronic signatures, as well as their legal recognition. It creates the legal basis for electronic signatures and certification services for the introduction of electronic signatures in the EU internal market. The Directive contains provisions on organizational and legal issues of access to the electronic services market. EU member states create the conditions for the organization of an effective system of control over the activities of certification service providers on their territory and are responsible for issuing valid certificates. In accordance with the principles of the internal market, EU member states must ensure the free distribution of electronic signature products in the internal market.

The wider dissemination of electronic methods of authenticity requires that electronic signatures be recognized as evidence in legal proceedings in EU Member States. Legal recognition of electronic signatures should be based on objective criteria and not be linked to the authority of a particular provider. According to Art. 5 Directives Member States should create conditions under which electronic signatures with secure signature-creation devices and certificates would comply with the legal requirements for signatures under information submitted in electronic form similar to handwritten signatures on paper. The legal force of an electronic signature cannot be denied simply because it has an electronic form of expression.

The EU Directive contains recommendations on the proper certification of electronic signatures. It is provided that in the process of certifying signatures it is necessary to ensure: compliance of the data specified in the certificate with the data confirming the signature; confirmation of the authenticity of signatures and their correct presentation for confirmation; the ability to establish the content of signed data; confirmation of the authenticity of the certificate during the certification of the signature; correct display of the result of confirmation and identification of the signatory; the ability to detect changes related to the security of the signature certificate.

Conclusions. At the legislative level in the EU there are provisions for the use of the latest information technologies that ensure the use of electronic documents and electronic digital signatures, the purpose of which is to harmonize the interests of EU member states, legal entities and citizens. EU directives in the field of e-commerce are designed to ensure maximum protection of the right to information and to ensure information security for the normal development of the information society and the stabilization of economic life.

\section{REFERENCES:}

1. Ананько А. Электронная форма сделки в международной торговле. URL: http:/www.russianlaw.net/law/doc/a124.htm.

2. Вершинин А.П. Электронный документ: правовая форма и доказательство в суде. Москва : Городециздат, 2000.242 с.

3. Дутов М. Сравнительный анализ европейского законодательства в области электронного документооборота. Предпринимательство, хозяйство и право. 2002. № 8. С. 25-28.

4. Завидов Б.Д. Электронная цифровая подпись: правовое значение. Москва : Экзамен, 2001.21 с.

5. Серго А.Г. Правовое регулирование электронной коммерции. URL: http://www.rol.ru/news/it/legal/interview.htm.

6. Соловьяненко Н. Электронная подпись в правовом лабиринте. eCommerce World. 2001. № 2. C. 16-22.

7. Чучковська А.В. Правове регулювання електронної комерції. Київ : ЦУЛ, 2007. 224 с.

8. Шамраев А. Развитие европейского права электронной коммерции. URL: www.e-managment.ru/e-law-euro.htm.

9. Язев А. Электронный документооборот: основыне понятия. Мир электронной комерциии. 2001. № 1. С. $22-27$.

10. Directive 2000/31/EC of the European Parliament and of the Council of 8 June 2000 on certain legal aspects of information society services, in particular electronic commerce, in the Internal Market (Directive on the electronic commerce). Official Journal of the European Communities. 2000. L 178.

11. Directive 1999/93/EC of the European Parliament and of the Council of 13 December 1999 on a Community Framework for Electronic Signatures (Electronic Signatures Directive). Official Journal of the European Communities. 1999. L 13

12. UNCITRAL Draft Model Law on Electronic Commerce. URL: http:/www.uncitral.org/texts/electcom/ml-ecomm.htm. 
Menso Iryna

LEGAL REGULATION OF E-COMMERCE IN THE EUROPEAN UNION

The research is based on current legislation of EU. On the grounds of this documentary basis the notion of e-commerce is analyzed, legal relationships related to this notion, the use of electronic documents and electronic signatures is discussed.

At the legislative level in the EU there are provisions for the use of the latest information technologies that ensure the use of electronic documents and electronic digital signatures, the purpose of which is to harmonize the interests of EU member states, legal entities and citizens. EU directives in the field of e-commerce are designed to ensure maximum protection of the right to information and to ensure information security for the normal development of the information society and the stabilization of economic life.

Gradually, a new concept of "e-commerce" appeared and became established in business and legal practice, but the legal basis for regulating e-commerce relations in the world is just beginning to be created. At the level of international organizations and legislation of some countries only since the 90 s of the twentieth century. Work began on the adoption of comprehensive regulations on the regulation of relations arising from the commission of legal acts through telecommunications networks, which is associated with the complexity and novelty of e-commerce.

The rapid technological development and the global extraterritorial nature of the Internet are the foundations of the ideology of openness to various technologies and services related to the conformity of the original data, including through electronics.

The modern world economy is currently at the stage of formation of the information society under the influence of the development of information technologies, the latest means of communication, the promotion of the global Internet. E-commerce involves the conclusion of commercial contracts online using electronic means of communication. It is, first of all, about the promotion of goods or services on the market through the global Internet, as well as settlements using electronic payment systems. The e-economy (web economy) deals with digital data and includes ways to make a profit using the Internet. The components of the electronic economy (web economy) are: Online stores, Online media, online advertising, online entertainment, etc.

Key words: electronic commerce (e-commerce), electronic digital signature, electronic document, European Union (EU).

\section{Менсо Ірина Володимирівна}

\section{ЕАЕКТРОННА КОМЕРЦІЯ У ЄВРОПЕЙСЬКОМУ СОЮЗІ: ПРАВОВЕ РЕГУАЮВАННЯ}

На підставі законодавства ЄС проведено аналіз поняття "електронна комерція", визначені правовідносини, які становлять це поняття, Аосліджено поняття та використання електронних документів та електронних піАписів.

У ЄС на законодавчому рівні закріплені положення щодо застосування новітніх інформаційних технологій, що забезпечують використання електронних документів і електронних цифрових підписів, метою яких є гармонізація інтересів країн-членів ЄС, юридичних осіб, громадян. Аирективи ЄС у сфері електронної комерції покликані забезпечити максимальний захист права на інформацію і гарантувати інформаційну безпеку задля нормального розвитку інформаційного суспільства та стабілізації економічного життя.

Поступово у Аіловій і правовій практиці з'явилося і закріпилося нове поняття "електронна комерція", проте правова база Аля регулювання відносин електронної комерції у країнах світу лише починає створюватися. На рівні міжнародних організацій і законодавства окремих країн світу лише з 90-х рр. XX ст. почалася робота із прийняття комплексних нормативно-правових актів, присвячених регулюванню відносин, котрі виникають при вчиненні правочинів через мережі електрозв'язку, що пов'язано зі складністю та новизною правовідносин електронної комерції.

ШвиАкий технологічний розвиток і глобальний екстериторіальний характер мережі Інтернетє засадами ідеології відкритості до різноманітних технологій і послуг, що належать до встановлення віАповідності даних оригіналу, в т. ч. за допомогою засобів електроніки.

Сучасна світова економіка нині перебуває на стадії становлення інформаційного суспільства піА впливом розвитку інформаційних технологій, новітніх засобів зв'язку, просування глобальної мережі Інтернет. Електронна (комерція) торгівля пов'язана з укладанням комерційних Аоговорів у режимі онлайн із використанням електронних засобів зв'язку. Йдеться насампереА про просування товару чи надання послуги на ринку за Аопомогою глобальної мережі Інтернет, а також заійснення розрахунків за допомогою електронних платіжних систем. Електронна економіка (веб-економіка) оперує з цифровими даними та включає в себе способи отримання прибутку із використанням мережі Інтернет. Складовою частиною електронної економіки (веб-економіки) є: Інтернет-магазини, Інтернет-ЗМІ, онлайн-реклама, онлайн-розваги та ін.

Ключові слова: електронна комерція, електронний документ, електронний цифровий піАпис, Європейський Союз (ЄС). 